\title{
Faktor-Faktor yang Mempengaruhi Penurunan Produksi Minyak Kelapa Murni (Lengis Tanusan) di Desa Antiga, Karangasem
}

\author{
I Nyoman Sunada \\ Program Studi Manajemen Tata Boga, Politeknik Pariwisata Bali \\ Jl. DharmawangsaKampial, Nusa Dua Bali, Telp: (0361) 773537 \\ sunada@gmail.com
}

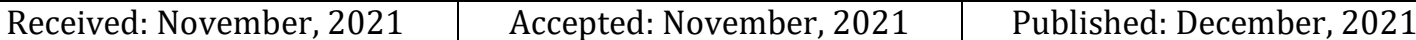

\begin{abstract}
The purpose of this study is to identify and describe the factors that influence the decline in the production of virgin coconut oil (lengis tanusan) in Angtiga Village, Karangasem, and the benefits of this research are expected to be information to the world of the catering industry and the public that virgin coconut oil has many benefits. advantages of ordinary vegetable oil. The theory used to solve the problem in this research is "Production Management" which discusses the factors of production, such as: Humans (Labour), Methods, Machines, Raw Materials and Types of Production. The research method, the object of this research is Pure Coconut Oil (lengis tanusan) in Antiga Village, Karangasem which is obtained from the results of observations and interviews. The data analysis technique in this research is descriptive qualitative. Based on the results of research that has been carried out at a virgin coconut oil production house in Antiga Village, Karangasem and discussions related to the factors that affect the decrease in the amount of production, it can be concluded that: Workers who are not given training so they are less able to work more effectively and efficiently, the method used in the manufacture of virgin coconut oil using heating, the lack of use of appropriate machines and the use of raw materials (coconut) is not maintained.
\end{abstract}

Keywords: production management, production factors, virgin coconut oil

\begin{abstract}
Abstrak
Tujuan dari penelitian ini adalah untuk mengetahui dan mendeskripsikan faktor-fator yang mempengaruhi penurunan produksi minyak kelapa murni (lengis tanusan) di Desa Angtiga, Karangasem, dan manfaat penelitian ini diharapkan dapat menjadi informasi kepada dunia industri jasa boga dan masyarakat bahwa minyak kelapa murni mempunyai banyak kelebihan dari minyak sayur biasa. Teori yang digunakan untuk memecahkan permasalah dalam penelitian ini adalah "Manajemen Produksi" yang membahas tentang faktor-faktor produksi, seperti: Manusia (Tenaga Kerja), Metode, Mesin, Bahan Baku dan Jenis-jenis Produksi. Metode penelitian, Objek penelitian ini adalah
\end{abstract}


I Nyoman Sunada

\begin{abstract}
Minyak Kelapa Murni (lengis tanusan) di Desa Antiga, Karangasem yang didapat dari hasil observasi dan wawancara. Teknik analisis data dalam penelitian ini adalah deskriptif kualitatif. Berdasarkan hasil penelitian yang sudah dilakukan di rumah produksi minyak kelapa murni di Desa Antiga, Karangasem dan pembahasan terkait faktor-faktor yang mempengaruhi penurunan jumlah produksi dapat disimpulkan bahwa: Tenaga kerja yang kurang diberikan pelatihan sehingga kuranng mampu bekerja lebih efektif dan efisien, metode yang digunakan dalam pembuatan minyak kelapa murni menggunakan cara pemanasan, kurangnya penggunaan mesin yang sesuai dan penggunaan bahan baku (kelapa) tidak dijaga kualitasnya
\end{abstract}

Kata kunci: manajemen produksi, faktor-faktor produksi, minyak kelapa murni

\title{
1. PENDAHULUAN
}

Kuliner Bali mempunyai ciri khasnya tersendiri baik itu dari segi rasa, aroma, dan juga teknik memasaknya. Makanan atau yang biasa disebut kuliner bagi masyarakat Indonesia mempunyai kaitan erat dengan tradisi suatu masyarakat, oleh karena itu kuliner di Indonesia mempunyai fenomena lokal yang menyangkut budaya dan tradisi suatu daerah yang diwarisi secara turun temurun, sehingga kuliner tersebut kuliner tradisional (Indrati dan Gardjito 2014). Kuliner Bali juga termasuk kuliner tradisional dimana kuliner Bali beberapa diantaranya digunakan untuk sarana persembahyangan bagi umat hindu yang ada di Bali. Selain itu, kuliner Bali juga sudah diturun-temurunkan dari generasi ke generasi baik melalui pembelajaran ataupun ketika melakukan kegiatan keagamaan yang ada kaitannya dengan kuliner.

Lebih lanjut Swarsi (dalam Rumadana, dkk 2012) mengklasifikasi makanan Bali menjadi dua yaitu ajengan dan amikan yang dimaksud dengan ajengan terdiri dari nasi yang dapat berupa nasi tulen (nasi putih atau nasi dari beras merah) dan nasi moran (berbahan dasar beras yang dicampur dengan umbi-umbian atau kacang jenis polongpolongan dan atau jagung), lauk peneman dari nasi disebut dengan istilah goh nasi dapat berupa be (ikan, daging dan unggas) jukut (sayuran berkuah atau campuran beberapa sayuran dengan bahan lain dan kelapa parut) be dan jukut (campuran sayuran dengan daging, ikan atau unggas dengan penampilan berkuah atau lembab) dan timbungan (daging, ikan atau unggas yang dicampur dengan sayuran dan bumbu, dimasukan ke dalam bambu yang masih hijau lalu dipanggang atau dibakar) serta sambel yang dapat berupa sambel matah/mentah, sambel kukus/tambus dan sambel megoreng (sambel yang digoreng sebelum disajikan). Sedangkan amikan adalah panganan kecil yang berfungsi sebagai makanan salingan yang tidak membuat perut kenyang terdiri dari imun-imunan (berbagai jenis minuman), who-wohan (buah-buahan), rujak, dan jaja (jajanan basah atau kering).

Dalam kuliner Bali banyak menggunakan bahan-nahan yang berasal dari alam ataupun bahan olahan dari alam itu sendiri. Penggunaan bahan ini dianggap oleh sebagian orang penyebab kuliner Bali mempunyai rasa dan aroma yang khas. Bukan hanya faktor asal dari bahan-bahan yang mempengaruhi hal tersebut, namun keberagaman jenis bahan yang digunakan juga menyebabkan kuliner Bali mempunyai chiri khas yang kuat dengan rasa rempahnya. Dari berbagai bahan yang digunakan dalam kuliner Bali ada salah satu bahan yang banyak dipandang sebelah mata oleh orang-orang dan sering diganti dengan bahan yang serupa yaitu minyak kelapa. Minyak kelapa digunakan dalam masakan bali karena memiliki aroma khas kelapa yang tentunya akan mempengaruhi aroma dari makanan yang dibuat dengan minyak kelapa.

Minyak goreng merupakan salah satu kebutuhan pokok manusia sebagai bahan pengolahan bahan-bahan makanan. Minyak goreng berfungsi sebagai media 
I Nyoman Sunada

penggorengan sangat penting dan kebutuhannya semakin meningkat. Minyak dapat bersumber dari tanaman, misalnya minyak zaitun, minyak jagung, minyak kelapa, dan minyak biji bunga matahari. Minyak juga dapat bersumber dari hewan, misalnya ikan sarden, ikan paus (Tangkudung, 2014). Minyak kelapa merupakan salah satu minyak goreng yang banyak digunakan di industri kuliner, terutama dalam pengolahan masakan nusantara. Minyak kelapa sering digunakan untuk menggoreng ikan, daging menumis sayuran atau dicampur begitu saja dengan bumbu mentah seperti dalam pembuatan sambel matah di Bali. Selain untuk sambel matah minyak kelapa juga banyak digunakan dalam proses pembuatan masakan Bali, seperti dalam membuat base genep minyak kelapa digunakan untuk menumis setelah dihaluskan.

Minyak kelapa murni dibuat dari kelapa yang segar dan dipanaskan tanpa bahan kimia. Selain itu, tidak melalui tahap pemurnian, pemucatan dan penghilang aroma. Biasanya, kelapa yang digunakan bukan kelapa hibrida, tetapi kelapa dalam atau kelapa liar sehingga kandungannya masih utuh dan tahan terhadap ketengikan (Sutarmi dan Rozaline, 2005). Keunggulan dari minyak ini menurut SNI adalah bau kelapa segar, tidak tengik, rasa normal, khas kelapa dan tidak berwarna. (Setiaji dan Prayugo, 2006). Minyak kelapa pada umumnya dibagi menjadi dua kategori yaitu minyak kelapa komersial yang telah di Refined, Deodorized, Bleached (RBD) dan minyak kelapa murni. Minyak kelapa komersial terbuat dari kopra (daging kelapa yang dijemur dibawah sinar matahari). Sesuai kondisinya, bahan ini relatif kotor dan mengandung bahan asing yang mempengaruhi hasil akhirnya. Bahan asing ini biasa berupa jamur, tanah, sampah dan kotoran lainnya (Gani, et al., 2005).

Salah satu daerah di Bali yang menjadi produsen minyak kelapa murni adalah Karangsem. Karangsem juga merupakan daerah yang mempunyai perkebunan kelapa yang melimpah. Namun, dalam beberapa tahun belakangan ini terjadi penurunan produksi kelapa di Karangasem, berikut paparan data produksi kelapa di Kabupaten Karangasem dari tahun 2015 sampai 2019.

Tabel 1: Luas Areal dan Produksi Kelapa di Kabupaten Karangasem Tahun 2015 - 2019

[Sumber: Dinas Kehutanan dan Perkebunan Kab. Karangasem]

\begin{tabular}{lccccc}
\hline \multirow{2}{*}{ URIAN } & \multicolumn{5}{c}{ TAHUN } \\
\cline { 2 - 6 } & 2015 & 2016 & 2017 & 2018 & 2019 \\
\hline \multicolumn{1}{c}{$(1)$} & $(2)$ & $(3)$ & $(4)$ & $(5)$ & $(6)$ \\
\hline $\begin{array}{l}\text { LUAS AREA } \\
\text { (Ha) }\end{array}$ & $17.693,00$ & $17.360,00$ & $17.308,12$ & $17.991,31$ & $17.693,00$ \\
$\begin{array}{l}\text { PRODUKSI } \\
\text { (Ton) }\end{array}$ & $13.749,00$ & $13.692,06$ & $14.451,04$ & $13.838,31$ & $13.445,00$ \\
\hline
\end{tabular}

Penurunan produksi kelapa ini juga berpengaruh pada jumlah pembuat minyak kelapa murni di Desa Angtiga, Karangasem yang menurun. Selain dipengaruhi menurunnya produksi kelapa, ada faktor lain yang mempengaruhi penurunan jumlah pembuat minyak kelapa murni, yaitu kurang pastinya jumlah produksi yang menyebabkan terkadang produsen minyak kelapa mengalami kerugian dan tidak mampu mengembalikan biaya produksi yang sudah dilakukan. Selain hal tersebut sulitnya bersaing dengan minyak sayur biasa, distribusi yang kurang mencapai target dan pengemasan minyak kelapa yang kurang mencolok dan terkadang hampir sama dengan minyak sayur biasa. Ketidakpastian hasil produksi dipengaruhi banyak hal, Selain dari bahan utama, alat produksi yang digunakan juga mempengaruhi hasil produksi minyak kelapa murni, alat yang digunakan di Desa Antiga Karangasem masih menggunakan alat tradisional karena akan menghasilkan aroma yang lebih kuat. Dua hal lain yang sangat mempengaruhi juga tenaga kerja dan proses pembuatannya. Tenaga kerja yang digunakan adalah masyarakat sekitar, sedangkan proses pembuatan yang dilakukan merupakan 
I Nyoman Sunada

proses pembuatan tradisional yang dimulai dari proses pemarutan daging buah kelapa, lalu dijadikan santan dan dimasak sampai menghasilkan minyak kelapa. Penggunaan alat masih menggunakan alat tradisional yang masih membutuhkan bantuan tenaga manusia.

Berdasarkan data di atas penulis mulai mewawancara pembuat minyak kelapa murni di Desa Angtiga, Karangasem yang masih melakukan produksi dan yang sudah berhenti melakukan produksi. Berdasarkan hasil wawancara yang penulis lakukan, punurunan ini terjadi sudah dari beberapa tahun belakangan ini dan dimulai dari tahun 2015 dan hingga saat ini. Berikut data penurunan jumlah produsen minyak kelapa murni di desa Antiga Karangasem dari tahun 2015 sampai dengan tahun 2019.

Tabel 2: Jumlah Produsen dan Jumlah

Produksi Minyak Kelapa Murni Per Hari

[Sumber : Kantor Desa Antiga]

\begin{tabular}{lccccc}
\hline \multirow{2}{*}{ URIAN } & \multicolumn{5}{c}{ TAHUN } \\
\cline { 2 - 6 } & 2015 & 2016 & 2017 & 2018 & 2019 \\
\hline JUMLAH & 16 & 14 & 13 & 10 & 8 \\
PRODUSEN & & 252 & 234 & 180 & 144 \\
$\begin{array}{l}\text { PRODUKSI } \\
\text { (Liter/Hari) }\end{array}$ & 288 & & & & \\
\hline
\end{tabular}

Tabel 2. diatas menunjukkan terjadinya penurunan jumlah produsen minyak kelapa murni dari tahun 2015 sampai tahun 2019 dan terjadi penurunan jumlah produksi minyak kelapa murni dari hari ke hari. Melihat penurunan yang terjadi maka besar kemungkinan akan terjadi kembali ditahun berikutnya, sedangkan keberadaan minyak kelapa murni sangatlah penting didalam pembuatan kuliner Bali. Penyebab utama banyak pembuat minyak kelapa berhenti adalah ketidakstabilan hasil produksi minyak kelapa yang mereka lakukan. Jika faktor-faktor yang mempengaruhi hasil produksi ini dapat dikendalikan tentu saja hasil produksi juga mampu dikendalikan juga, dan penurunan produksi minyak kelapa murni diharapkan tidak terjadi lagi hanya dikarenakan hasil produksi yang tidak konsisten.

Berdasarkan latar belakang diatas maka permasalahan yang dapat diidentifikasi yaitu jumlah produksi yang tidak tentu, penurunan jumlah produksi kelapa di Karangasem, tenaga kerja yang kurang memahami manajemen produksi yang mempengaruhi hasil produksi dan proses pembuatan yang masih menggunakan metode tradisional.

Penelitian ini bertujuan untuk menemukenali faktor-faktor yang mempengaruhi penurunan produksi minyak kelapa murni (lengis tanusan) di Desa Angtiga, Karangasem.

\section{METODE PENGUMPULAN DATA}

Pendekatan penelitian ini menggunakan pendekatan penelitian kualitatif berupa hasil wawancara dan observasi mengenai Minyak Kelapa Murni (lengis tanusan) di Desa Antiga, Karangasem. Objek penelitian ini adalah Minyak Kelapa Murni (lengis tanusan) dengan lokasi penelitian di Banjar Bengkel, Desa Antiga, Karangasem.

Sumber data dalam penelitian ini yaitu data primer yang berupa data hasil wawancara dan observasi langsung ke Banjar Bengkel, Desa Antiga, Karangasem dan data sekunder dimana peneliti memperolehnya dari sumber-sumber literature, jurnal dan hasil penelitian sebelumnya.

Teknik Pengumpulan Data dalam penelitian ini dengan mengadakan wawancara dan observasi ke Banjar Bengkel, Desa Antiga, Karangasem. Teknik analisis data yang digunakan dalam penelitian ini adalah deskriptif kualitatif. Hasil wawancara dan observasi mengenai faktor-faktor yang mempengaruhi hasil produksi minyak kelapa murni (lengis tanusan), disusun secara sistematis, disajikan dalam bentuk narasi serta tabel, dan ditarik simpulan dari hasil penelitian. 


\section{HASIL DAN PEMBAHASAN}

\subsection{Gambaran Umum Objek Penelitian}

Produksi minyak kelapa murni dilakukan setiap dua hari sekali, ini menyesuaikan dengan hari dimana dilakukannya proses pengumpulan kelapa-kelapa di seputaran Desa Angtiga. Pemilik yaitu Pak Wayan Suardana sudah memliki jadwal dengan pemilik kebun kelapa, jadi proses pengumpulan kelapa rutin terjadi setia 2 hari sekali. Sekali produksi menggunakan 350 butir kelapa dimana umumnya 8-10 butir kelapa menjadi 1 liter minyak kelapa. Proses produksi minyak kelapa di mulai dari jam 5 pagi dan selesai jam 3 sore. Tenaga kerja yang terdapat di pabrik ini ada 5 orang yang merupakan ibu rumah tangga yang sebelumnya melakukan produksi minyak kelapa rumahan dan kemudian dipekerjakan di pabrik. Setiap pegawai memiliki tugas mereka masing-masing ketika produksi berlangsung.

Produksi yang dilakukan merupaka produksi terus menerus karena produksi dulakukan secara rutin dan satu hari produksi sudah langsung menghasilkan produk. Produksi minyak kelapa murni bisa dikatakan sebagai budaya turun temurun, karena produksi minyak kelapa sudah dilakukan dari dulu dan selalu diturun-temurunkan ke generasi selanjutnya, ini berdasarkan hasil temuan dari hasil wawancara dengan tenaga kerja.

Lokasi pembuatan minyak kelapa ini berdekatan dengan Banjar Bengkel, Desa Antiga, Karangasem. Rumah produksi berada tepat di depan gudang tempat pengepul kelapa yang juga dimiliki oleh Pak Wayan Suardana. Rumah produksi di bagi menjadi 3 bagian yaitu tempat bakaran atau tempat pemanasan santan, lalu tempat pencucian kelapa yang juga dijadikan tempat pemerasan parutan kelapa dan yang terkahir tempat untuk memarut kelapa dimana terdapat satu mesin parut disana. Rumah produksi ini tergolong cukup minimalis karena hanya di kelilingi dengan tembok batako dibagian kiri dan kanan lalu terbuka dibagian belakang untuk tempat pemansan santan yang memerlukan ruang terbukan agar asap hasil pembakaran tidak diam didalam ruangan.

Minyak kelapa yang dihasilkan di desa antiga Karangasem sering disebut sebagai lengis tanusan atau minyak kelapa yang dihasilkan dari proses nandusin. Nandusin sendiri merupakan proses pemanasan santan sampai menjadi minyak kelapa. Proses ini memerlukan waktu kurang lebih 12 jam dari proses pembersihan kelapa sampai jadi minyak kelapa. Proses produksi ini menghasilkan 3 item yaitu minyak kelapa(lengis tanusan), telengis dan roroban.

Minyak kelapa murni ini dikemas dengan menggunakan botol bekas air mineral dengan ukuran1,5 liter. Warna minyak kelapa murni hasil produksi memili warna yang bening kekuningan serta aroma kelapa yang kuat. Hal tersebutlah yang menjadi keunggalan minyak kelapa murni hasil produksi desa antiga Karangasem. Kelapa yang digunakan dalam proses produksi minyak kelapa berasal dari perkebunan kelapa milik warga sekitar yang dikumpulkan oleh pengepul kelapa. Berikut merupakan bagan proses produksi minyak kelapa murni yang dilakukan di Desa Antiga, Kangasem. Adapun Proses pembuatan minyak kelapa murni yang dillakukan di desa Angtiga Karangsem terdapat 8 tahapan proses, yaitu sebagai berikut.

Pengupasan Batok Kelapa dimana kelapa yang datang dari gudang kelapa adalah kelapa yang sudah tidak ada serabut kelapanya.Jadi dalam proses pertama dilakukan pembersihan atau pemisahan daging buah kelapa dengan batok kelapa. Kemudian daging kelapa akan dilanjukan ke proses selanjutnya sedangkan batok kelapa akan dikumpulkan kemudian dijual.

Pemotongan dan Pencucian kelapa dimana kelapa yang digunakan adalah kelapa yang pecah ketika proses pemanenan dan tidak bisa dijual, sehingga membutuhkan proses pencucian untuk menghilangkan kotoran yang mungkin terdapat di kelapa. Kelapa yang 
I Nyoman Sunada

dicuci dalam bentuk sudah di bersihkan dari kulit dan batok kelapanya serta sudah dipotong dengan ukuran yang lebih kecil. Dilakukan 2 kali proses pencucian untuk memamastika tidak terdapatnya kotoran di kelapa. Pencucian tidak dilakukan jika kelapa yang digunakan adalah kelapa yang utuh.

Pemarutan Kelapa dengan menggunakan mesin parut yang tergolong tradisional atau belum menggunakan teknologi yang modern, karena masih menggunakan tenaga manusia untuk mendorong kelapa ke dalam mesin parut, pemarutan dilakukan setelah pencucian kelapa selesai dilakukan. Ada beberapa jumlah kelapa yang terbuang ketika proses pemarutan kelapa tersebut namun jumlahnya tidak terlalu banyak, bisa dikatakan kurang dari $1 \%$ dari total kelapa yang diparut.

Pemerasan Parutan Kelapa Menjadi Santan dimana kelapa yang sudah diparut ditambahkan air lalu di peras sehingga menghasilkan santan, pemerasan menggunakan kain kasa untuk membantu memisahkan parutan kelapa dengan santannya. Penyaringan dilakukan 2 kali untuk memastikan tidak ada parutan kelapa yang terlewat. Sebelumnya pemilik sempat menggunakan mesin yang membantu dalam proses pemerasan santan, namun tidak digunakan lagi karena santan yang dihasilkan lebih sedikit dibandingkan dengan hasil yang tanpa menggunkan mesin.

Selanjutnya tahap pemanasan santan dengan menggunakan panci-panci yang berukuran besar dan untuk tempat apinya menggunakan tempat bakaran tradisional yang terbuat dari bata yang disusun. Dan bahan bakarnya menggunakan sabut kelapa atau yang umum dikatakan sambuk oleh masyarakat Bali. Santan dipanaskan selama 4 jam sampai minyak kelapa naik ke permukaan.

Pengadukan santan dan penambahan air dilakukan setelah minyak yang terlihat setelah 2 jam proses pemanasan lalu akan ditambah air untuk menambah volume santan untuk mengurangi resiko santan habis sebelum 4 jam proses pemanasan. Selama proses pemanasan dilakukan proses pengadukan yang bertujuan untuk meratakan suhu santan yang dibagian bawah dan dibagian atas.

Santan yang sudah dipanaskan selama 4 jam akan mendapatkan 3 hasil yaitu, minyak kelapa(lengis tanusan),telengis atau ampas dari proses pemanasan dan roroban atau air sisa dari proses pemanasan santan. Minyak akan disaring atau diambil dengan menggunakan ladle tardisional. Proses pengambilan minyak kelapa ini hampir mirip dengan proses skiming dalam proses pembuatan kaldu yaitu mengambil buih-buih yang keluar ketika proses pemanasan kaldu tersebut. Setelah minyak kelapa diambil, minyak kelapa akan didinginkan sekitar 30 menit di dalam panci lalu dipindahkan kedalam botol air mineral berukuran 1,5 liter.

Ampas dari proses pemanasan santan disebut telengis oleh warga sekitar ini merupakan salah satu bahan yang dapat dimanfaatkan sebagai salah satu makanan bali yaitu pesan telengis. Telengis akan disaring menggunakan kain kasa untuk mengurangi kadar air yang terdapat pada telengis. Telengis yang baik umumnya memiliki kadar air yang sedikit sehingga ketika diproses menjadi pesan telengis, pesan telengis tidak akan berair.

\subsection{Analisis Data}

Guna menganalisis data yang sudah dipaparkan di atas, penulis menggunakan teori manajemen produksi dari T. Hani Handoko dimana adapun faktot-faktor yang mempengaruhi proses produksi yaitu sebagai berikut.

Sumber daya manusia adalah unsur utama yang memungkinkan terjadinya proses penambahan nilai. Kemampuan mereka untuk melakukan suatu tugas adalah kemampuan, pengalaman, pelatihan dan potensi kreativitas yang beragam, sehingga diperoleh suatu hasil. Manusia merupakan salah satu faktor utama dalam sebuah produksi, karena manusialah yang menjalankan proses produksi tersebut. Walaupun terkadang di beberapa proses produksi sudah didukung oleh mesin-mesin yang canggih guna mempercepat 
I Nyoman Sunada

maupun mempermudah proses produksi. Namun, manusia masih tetap dibutuhkan untuk menjalankan mesin-mesin tersebut, manusia juga dibutuhkan untuk memprogram mesin tersebut agar berfungsi sesuai dengan kebutuhan produksi. Tenaga kerja yang dipekerjakan di rumah produksi minyak kelapa murni di Desa Antigamerupakan ibu-ibu rumah tangga yang sebelumnya merupakan produsen minyak kelapa murni rumahan. Ibuibu ini sebelumnya melakukan produksi minyak kelapa untuk keperluan pribadi dan terkadang diperjualkan juga. Mereka sudah melakukan produksi rumahan semenjak mereka remaja, ini dikarenakan dulu orang tua mereka juga memproduksi minyak kelapa murni untuk kebutuhan pribadi dan diperjualkan. Sehingga berdasarkan hal tersebut, ibuibu ini sudah sangat memahami proses produksi minyak kelapa murni dengan tehnik pemanasan atau yang disebut dengan istilah nandusin dalam bahasa bali. Dari segi pengalaman, tenaga kerja yang bekerja di rumah produksi memiliki pengalaman yang sangat cukup dikarenakan mereka sudah melakukan produksi semenjak remaja. Namun mereka hanya memahami proses produksi dengan cara pemanasan dan masih tergolong tradisional, untuk metode pembuatan yang lain mereka tidak mengetahuinya. Jadi manusia atau tenaga kerja yang ada di rumah produksi minyak kelapa murni di Desa Antigadapat dikatagorerikan sudah terlatih untuk proses produksi minyak kelapa dengan menggunakan cara pemanasan. Namun untuk metode cara pembuatan minyak kelapa yang lain mereka belum terlatih.

Metode dalam pembuatan minyak kelapa ada 3 yaitu dengan cara pemanasan, cara fermentasi dan cara sentrifugasi. Dari ketiga cara tersebut memiliki kekurangan dan kelebihannya masing-masing. Cara pemanasan memiliki kelebihan dari hasil akhir yaitu, minyak memiliki aroma kelapa yang lebih kuat dibandingkan dengan cara fermentasi dan cara sentrifugasi. Namun cara pemanasan memerlukan proses yang sangat banyak dibandingkan dengan kedua cara yang lainnya. Selain proses yang cara pemanasan juga memerlukan biaya produksi yang besar dikarenakan membutuhkan api untuk memanaskan sampai mengeluarkan minyak kelapa. Di rumah produksi minyak kelapa murni di Desa Antigamenggunakan cara pemanasan, dimana kelapa yang sudah dijadikan santan dipanaskan selama kurang lebih 4 jam. Ada tahapan yang tidak dilakukan di sini yaitu santan tidak di peram selama 12 jam untuk mendapatkan krim yang akan dipanaskan, tetapi santan yang sudah jadi langsung dipanaskan untuk mendapatkan minyak kelapa. Proses santan yang di peram selama 12 jam terdapat pada teori Rindengan dan Karouw dalam Peluang pengembangan minyak kelapa murni. Prosiding Konferensi Nasional Kelapa V. Tembilahan. Dengan menggunakan metode pemanasan minyak kelapa yang dihasilkan rumah produksi minyak kelapa murni di Desa Antiga memiliki aroma kelapa yang kuat dan ini menjadi keuunggulan dari minyak kelapa hasil produksi Desa Antiga Karangasem. Biaya produksi yang dikeluarkan untuk metode pemanasan ini tergolong kecil karena menggunakan tungku bakaran yang tradisional sehingga bahan bakarnya menggunakan serabut kelapa yang didapat dari proses pembersihan buah kelapa. hanya waktu produksi yang memakan waktu kurang lebih 10 jam, dari proses pembersihan kelapa sampai minyak kelapa siap dipakai.

Mesin atau peralatan yang digunakan dalam proses penambahan nilai menjadi output. Dengan memakai mesin sebagai alat pendukung pembuatan suatu produk, memungkinkan berbagai variasi dalam bentuk jumlah, dan kecepatan proses penyelesaian kerja. Mesin yang terdapat di rumah produksi minyak kelapa murni di Desa Antiga hanya mesin parut kelapa. Seperti pada Gambar 4.13. Mesin ini berfungi untuk memarut kelapa yang sudah dicuci sebelumnya. Mesin ini hanya mampu memarut kelapa yang berukuran kecil saja sehingga kelapa harus dipotong dengan ukuran yang lebih kecil terlebihdahulu sebelum dimasukan kedalam mesin ini. Mesin ini masih belum otomatis karena masih membutuhkan bantuan manusia untuk mendorong kelapa kedalam mesin ini. Jadi harus ada satu orang pegawai yang harus mendorong kelapa ketika proses pemarutan berlangsung. Sebelumnya pemilik sempat menggunakan mesin peras untuk memudahkan 
I Nyoman Sunada

proses pemerasan parutan kelapa menjadi santan, akan tetapi mesin tersebut tidak digunakan lagi karena hasil santan dari mesin peras tersebut lebih sedikit dibandingkan memeras mengunakan tenaga manusia dan dibantu dengan kain kasa untuk mencegah parutan kelapa masuk kedalam santan. Jadi, pemanfaatan mesin di rumah produksi minyak kelapa murni di desa antiga karangasam masih belum optimal, karena hanya memanfaatkan satu mesin saja dalam proses produksi dan mesin tersebut masih tergolong tradisional, sesungguhnya pemanfaatan mesin-mesin lainnya dapat digunakan guna mengefisienkan proses produksi yang memakan waktu kurang lebih 10 jam. Pemanfaatan mesin-mesin sesungguhnya mampu memangkas waktu produksi namun juga dapat berpengaruh pada hasil produksi seperti yang terjadi pada mesin press yang sudah sempat dicoba dipergunakan oleh pemilik untuk mempercepat proses pemerasan parutan kelapa menjadi santan. Selain itu, pemilihan mesin yang akan digunakan harus tepat dan dipahami oleh pegawai guna menstabilkan antara efisiensi proses produksi dengan hasil produksi.

Bahan baku dalam proses pembuatan minyak kelapa adalah kelapa. bagian kelapa yang digunakan adalah bagisan dagingnya. Daging kelapa akan diparut lalu dijadikan santan kemudian akan diproses sehingga menghasilkan minyak kelapa. Dari berbagai macam kelapa yang ada di Indonesia, kelapa yang paling cocok untuk diolah dijadikan minyak kelapa adalah kelapa raja,dikarenakan ukuran yang lebih besar sehingga jumlah santan yang akan didapat juga lebih banyak. Di rumah produksi minyak kelapa murni di Desa Antiga Karangasem juga menggunakan kelapa raja, itu dikarenakan kelapa yang tumbuh di perkebunan warga sekitar adalah kelapa raja. Kelapa raja yang digunakan adalah kelapa raja yang sudah matang lalu didiamkan hingga berwarna coklat dikeseluruhan kulit kelapanya. Itu dilakukan guna mengurangi kadar air di dalam kelapa. Hal ini berdasarkan pengalaman produksi para pegawai yang sudah bertahun-tahun melakukan produksi. Adapun proses perubahan warna kelapa yang akan terjadi adalah seperti berikut. Pertama kelapa yang baru di panen berwarna hijau di seluruh bagian permukaan kulitnya. Kemudian warna kuning kecoklat akan mulai muncul dipermukaan kulit kelapa, namun belum dikeseluruhan kulit kelapa. Kelapa yang sudah mengalami perubahan seperti ini terkadang sering digunakan juga, jika jumlah kelapa yang sudah siap digunakan kurang. Dan setelah didiamkan kurang lebih selama 4 hari kelapa raja akan berwarna coklat diseluruh bagian kulitnya dan siap diproses untuk menjadi minyak kelapa murni.

\section{KESIMPULAN}

Berdasarkan paparan pada pembahasan yang telah diuraikan sebelumnya maka simpulan pada penelitian ini adalah tenaga kerja yang kurang diberikan pelatihan oleh pemilik rumah produksi minyak kelapa sehingga kuranng mampu bekerja lebih efektif dan efisien, metode yang digunakan dalam pembuatan minyak kelapa murni menggunakan cara pemanasan, kurangnya penggunaan mesin yang sesuai guna membantu proses produksi baik dari segi kecepatan produksi dan juga jumlah produksi, penggunaan bahan baku (kelapa) yang dicampur dengan kelapa yang sudah pecah yang bukan merupakan kelapa yang baik digunakan untuk pembuatan minyak kelapa.

\section{DAFTAR PUSTAKA}

Ahyari, A. (2011). Manajemen Produksi Perencanaan Sistem Produksi, Yogyakarta: BPFE. Assauri, S. (2016). Manajemen Produksi (Perencanaan Sasaran Organisasi Berkesinambungan). Edisi 3. Jakarta: PT Raja Grafindo Persanda.

Azwar, S. (1998). Metode penelitian. Yogyakarta: Pustaka pelajar.

Bartono, P.H. \& Ruffino, E.M. (2010). Tapa Tata Boga Industry. Yogyakarta: Andi

Barlina, R., Karouw, S., T. \& Hutapea, R. (2007). Pengaruh Perbandingan Air Kelapa dan Penambahan Daging Kelapa Muda Serta Lama Penyimpanan Terhadap Serbuk 
I Nyoman Sunada

Minuman Kelapa. Jurnal Littri, 13 (12), 73-80 Balai Penelitian Tanaman Kelapa dan Palma Lain (Balitka)

Fahmi, I. (2013). Pengantar Manajemen Keuangan. Bandung: Alfabeta.

Gani, A. (2005). Mengenal Lebih Dekat Minyak Kelapa Murni. Jakarta: Raja Grafindo.

Gaspersz, V. (2010). Total Quality Management (TQM). Jakarta: PT. Gramedia Pustaka Utama.

Handoko, T. H. (2002). Manajemen Personalia dan Sumber Daya Manusia. Yogyakarta : BPFE.

Hidayat, S. \& Sedamayanti. (2002). Metodologi Penelitian. Bandung: Mandar Maju.

Hui, Y. H. (1996). Bailey's Industrial Oil and Fat Products. 5 th Edition Vol 5. John Willey \& Sons, Inc, New York.7.

Indrati, R. \& Gardjito, M. (2014). Pendidikan Konsumsi Pangan: Aspek Pengolahan dan Keamanan. Jakarta: Kencana Prenada media Group.

Kasiram, M. (2008). Metodologi Penelitian. Malang: UIN-Malang Pers.

Manahan, P. T. (2014). Manajemen Operasi \& Rantai Pemasok (Operation and Supply-chain Management). Jakarta: Mitra Wacana Media.

Pemerintah Kabupaten Karangasem. (2015). Profil Daerah Kabupaten Karangasem Tahun 2014.

dari

http://v2.karangasemkab.go.id/assets/download/Profil\%20Daerah\%20Kab upaten\%20Karangasem\%20Tahun\%202014_521144.pdf.

Reksohadiprodjo, S. (1994). Produksi Tanaman Hijauan Makanan Ternak Tropik. Edisi Ketiga. Badan Penerbit Fakultas Ekonomi, Yogyakarta.

Rindengan, \& S. Karaow. (2003). Peluang pengembangan minyak kelapa murni. Prosiding Konferensi Nasional Kelapa V. Tembilahan, 22 - 24 Oktober 2002. 146 -153.

Sugiyono. (2010). Metode Penelitian Pendidikan Pendekatan Kuantitatif, kualitatif, dan R\&D. Bandung: Alfabeta.

Sugiyono. (2011). Metode Penelitian Kuantitatif, Kualitatifdan R\&D. Bandung: Afabeta.

Sugiyono. (2012). Metode PenelitianKuantitatif, Kualitatif, dan $R \& D$ (edisiXVII). Bandung: Alfabeta.

Supadi, N. AR. (2006). Pemberdayaan petani kelapa dalam upaya peningkatan pendapatan. Jurnal Litbang Pertanian, 1, 26

Tangkudung, M. (2014). Perubahan kadar asam lemak bebas pada minyak goreng curah, minyakjagung dan minyak zaitun setelah proses penggorengan berulang. Thesis, Universitas Negeri Gorontalo. 